\title{
PENGARUH KUALITAS PELAYANAN TERHADAP KEPUASAN MASYARAKAT PADA DINAS KEPENDUDUKAN DAN PENCATATAN SIPIL KABUPATEN LABUHANBATU
}

\author{
Siti Lam'ah Nasution \\ Dosen Tetap Sekolah Tinggi Ilmu Ekonomi (STIE) Labuhanbatu
}

\begin{abstract}
ABSTRAK
Meningkatnya jumlah penduduk di Labuhanbatu mendorong untuk dilakukannya pelayanan data kependudukan yang baik karena data kependudukan sangat diperlukan dalam perencanaan dan evaluasi pembangunan. Tujuan penelitian ini adalah: Untuk mengetahui pengaruh kualitas pelayanan terhadap kepuasan masyarakat pada Dinas Kependudukan dan Pencatatan Sipil Kabupaten Labuhanbatu.

Pada penelitian ini menggunakan data kuantitatif, yaitu dengan cara menyebarkan kuesioner kepada responden. Responden diminta melakukan penilaian berupa angka tentang layanan yang diberikan oleh Dinas Kependudukan dan Pencatatan Sipil Kabupaten Labuhanbatu.Skala yang digunakan penulis dalam penelitian ini adalah skala Likert.

Hasil penelitian menunjukkan bahwa Kebijakan sentralisasi pengurusan kartu tanda penduduk merupakan langkah maju Pemerintah Kabupaten Labuhanbatu terutama dalam bidang pelayanan public untuk mengetahui pengaruh kualitas pelayanan terhadap kepuasan masyarakat pada Dinas Kependudukan dan Pencatatan Sipil Kabupaten Labuhanbatu. Berdasarkan hasil penelitian kualitas pelayanan di Dinas Kependudukan dan Pencatatan Sipil Kabupaten Labuhanbatu tidak berpengaruh signifikan terhadap kepuasan masyarakat yang membutuhkan pelayanan tersebut, hal ini ditunjukkan dengan rendahnya nilai $R^{2}$ sebesar 0,01 dan hasil uji T menunjukkan tidak signifikan antara kualitas pelayanan terhadap kepuasan masyarakat.
\end{abstract}

\section{Kata kunci : Kualitas Pelayanan dan Tingkat Kepuasan Masyarakat.}

\section{Latar Belakang Masalah}

Sebagai konsekuensi dari pelaksanaan otonomi daerah, Pemerintah Daerah dituntut untuk meningkatkan kinerjanya dalam rangka memberikan pelayanan kepada masyarakat. Pada hakekatnya penyelenggaraan otonomi daerah diarahkan untuk mempercepat terwujudnya kesejahteraan masyarakat melalui peningkatan pelayanan, pemberdayaan dan peran serta masyarakat, serta peningkatan daya saing daerah.

Ada banyak penjelasan yang bisa digunakan untuk memahami mengapa pemerintah dan birokrasinya gagal mengembangkan kinerja pelayanan yang baik. Dengan menggunakan metafora biologi, OsborndanPlastrik (1998) menjelaskan lima DNA, kode genetika, dalam 
tubuh birokrasi dan pemerintah yang mempengaruhi kapasitas dan perilakunya. Sikap dan perilaku dari suatu birokrasi dan pemerintah dalam menyelengarakan pelayanan publik akan sangat ditentukan oleh bagaimana kelima DNA dari birokrasi itu dikelola, yaitu misi (purpose), akuntabilitas, konsekuensi, kekuasaan dan budaya. Kelima sistem DNA ini akan saling mempengaruhi satu sama lainnya dalam membentuk perilaku birokrasi publik. Pengelolaan dari kelima sistem kehidupan birokrasi ini akan menentukan kualitas sistem pelayanan publik.

\section{Perumusan Masalah}

Berdasarkan latar belakang dan batasan masalah dapat dirumuskan yaitu. Bagaimanakah pengaruh kualitas pelayanan terhadap kepuasan masyarakat pada Dinas Kependudukan dan Pencatatan Sipil Kabupaten Labuhanbatu?

\section{Tujuan dan Manfaat Penelitian}

Adapun tujuan penelitian berdasarkan rumusan masalah adalah :

Untuk mengetahui pengaruh kualitas pelayanan terhadap kepuasan masyarakat pada Dinas Kependudukan dan Pencatatan Sipil Kabupaten Labuhanbatu

Manfaat dari penelitian ini yaitu

1. Diharapkan dapat melengkapi bahan penelitian selanjutnya dalam rangka menambah khasanah akademik sehingga berguna untuk mengembangkan ilmu.

2. Sebagai bahan penilaian dan informasi Dinas tersebut berkaitan dengan kualitas pelayanan dan kinerja karyawan.

3. Untuk mengevaluasi kinerja para karyawan dan mengetahui seberapa besar tingkat kepuasan pelanggan kualitas pelanggan terhadap kepuasan masyarakat

4. Menambah wawasan dan pemahaman peneliti mengenai pengaruh kualitas pelayanan dan kinerja pegawai terhadap kepuasan masyarakat pada Dinas Kependudukan dan Pencatatan Sipil Kabupaten Labuhanbatu jika dipengaruhi oleh kualitas pelayanan dan kinerja pegawai. 


\section{Tinjauan Teoritis 1. Pengertian Kepuasan Pelanggan}

Kepuasan pelanggan merupakan salah satu kunci keberhasilanusaha. Hal ini dikarenakan dengan memuaskan pelanggan, perusahaandapat meningkatkan tingkat keuntungannya. Dalam hal ini yang akandibahas adalah perusahaan jasa. Konsumen dalam menggunakan jasatertentu akan menghasilkan tingkat kepuasan tertentu. Dari serviceperformance (tampilan pelayanan), maka perceived service (pelayananyang diberikan) tidak mungkin selalu sama dengan customerexpectation (harapan konsumen).

Kepuasan konsumen merupakan evaluasi atau penilaian kognitifmenyangkut apakah kinerja produk/jasa relatif bagus atau tidak.Masalah kepuasan adalah merupakan masalah perseorangan yangsifatnya subjektif, karena kepuasan sesorang belum tentu sama dengankepuasan yang dirasakan orang lain. menurut Engel, et al. (1990) dalam buku Tjiptono(2000) mengungkapkan bahwa kepuasan pelanggan merupakan evaluasi purna beli dimana alternatif yang dipilih sekurangkurangnyamemberikan hasil (outcome) yang sama atau melampaui harapanpelanggan, sedangkan ketidakpuasan timbul apabila hasil yang diperoleh tidak memenuhi harapan pelanggan. Pendapat lainmenyatakan bahwa kepuasan pelanggan adalah perasaan seseorangyang puas atau sebaliknya setelah membandingkan antara kenyataan dan harapan yang diterima dari sebuah produk atau jasa (Kotler2000:36).Kepuasan pelanggan hanya dapat tercapai dengan memberikanpelayanan yang berkualitas kepada konsumennya. Dalam memenuhi harapan pelanggan, perusahaan perlu mengetahui tingkat ekspektasikonsumen. Kepuasan konsumen yang tinggi akan meningkatkanloyalitas konsumen. Pelayanan yang baik sering dinilai oleh konsumensecara langsung dari karyawan sebagai orang yang melayani atau disebut juga sebagai produsen jasa, karena itu diperlukan usaha untuk meningkatkan kualitas sistem pelayanan yang diberikan agar dapatmemenuhi keinginan dan meningkatkan kepuasan konsumen 


\section{Kualitas Pelayanan a. Pengertian Kualitas}

Definisi kualitas mengandung banyak pengertian, menurut Kamus Bahasa Indonesia, kualitas berarti :

1) Tingkat baikburuknyasesuatu;

2) Derajatatautaraf (kepandaian, kecakapan, dansebagainya) ataumutu.

Pengertian kualitas menurut Fandy Tjiptono (1995:24) adalah :

1) Kesesuaiandenganpersyaratan;

2) Kecocokan untuk pemakaian;

3) Perbaikan berkelanjutan;

4) Bebas dari kerusakan atau kecacatan;

5) Pemenuhan kebutuhan pelanggan sejak awal dan setiap saat;

6) Melakukan segala sesuatu dengan benar;

7) Sesuatu yang bias membahagiakan pelanggan.

Buddy (1997) dalam Anis Wahyuningsih (2002:10) mendefinisikan, "kualitas sebagai suatu strategi dasar bisnis yang menghasilkan barang dan jasa yang memenuhi kebutuhan dan kepuasan konsumen internal dan eksternal, secara eksplisit dan implisit”.

\section{Pengukuran Kepuasan Pelanggan}

Berdasarkan pada keputusan Menteri Pendayagunaan Aparatur Negara Nomor:KEP/25M.PAN/2/2004 untuk mengukur tingkat kepuasan pelanggan atau masyarakat perlu adanya indeks kepuasan. Indeks kepuasan merupakan data dan informasi tentang tingkat kepuasan pelanggan atau masyarakat yang diperoleh dari hasil pengukuran kualitatif dan kuantitatif atas pendapat pelanggan dalam memperoleh pelayanan dengan membandingkan atas harapan dan kebutuhan. Indeks kepuasan pelanggan tersebut dikembangkan menjadi 14 unsur yang relevan, valid dan reliabel sebagai unsure minimal yang harus ada.

Berdasarkan pengukuran kepuasan pelayanan seperti yang telah dijelaskan diatas, maka instrumen yang akan digunakan dalam kuesioner meliputi :

1) Prosedurpelayanan

2) Persyaratanpelayanan 
3) Kejelasandankompetensi/kemampuan

4) Keadilanmendapatkanpelayanan

5) Kepastianjadwalpelayanan

6) Kenyamananlingkungan

7) Keamananpelayanan

\section{Strategi Kepuasan Pelanggan}

Mudie dan Cottam (1993) menyatakan bahwa kepuasan pelanggan total tidak mungkin tercapai, sekalipun hanya untuk sementara waktu. Namun upaya perbaikan atau penyempurnaan kepuasan dapat dilakukan dengan berbagai strategi. Kepuasan pelanggan merupakan strategi panjang yang membutuhkan komitmen, baik menyangkut dana maupun sumberdaya manusia (Schnaars, 1991).

\section{Hipotesis Penelitian}

Hipotesis yang diajukan pada penelitian ini adalah Terdapat pengaruh positif antara kualitas pelayanan terhadap kepuasan masyarakat.

\section{Metode Penelitian 1. Lokasi Penelitian}

Lokasi penelitian yang dilakukan Penulis adalah di Dinas Kependudukan dan Pencatatan Sipil Kabupaten Labuhanbatu yang merupakan sebuah instansi/lembaga yang bergerak di bidang pelayanan administrasi kependudukan dan pencatatan sipil kabupaten labuhanbatu yang beralamat di Jl. Meranti No. 1 Kel. Padang Matinggi, Kec. Rantau Utara (Depan Dinas Perpustakaan dan Kearsipan Kabupaten Labuhanbatu).

\section{Jenis dan Sumber Data}

Metode yang digunakan dalam penelitian ini adalah metode deskriptif. Metode deskriptif bertujuan untuk memberi gambaran tentang suatu masyarakat atau suatu kelompok orang tertentu atau gambaran tentang suatu gejala atau hubungan antara dua gejala atau lebih. Penelitian deskriptif adalah akumulasi data dasar dalam cara deskriptif semata-mata tidak perlu mencari, atau menerangkan saling berhubungan, mengetest hipotesis, membuat ramalan 
atau mendapatkan makna dan implikasi. Walaupun penelitian yang bertujuan untuk menemukan hal-hal tersebut dapat mencakup metode-metode deskriptif (Suharsimi Arikunto, 2002: 237). Penelitian ini bersifat kuantitatif, yaitu penelitian yang pemecahan masalahnya dengan berdasarkan angka-angka atau dapat diambil kesimpulan dan diberi saran-saran.

\section{Tenik Pengumpulan Data}

Teknik pengumpulan data yang digunakan dalam penelitian ini adalah menggunakan teknik pengumpulan data primer yang mana data dikumpilkan dari sumber data yang asli dari lapangan melalui pemberian kuesioner sesuai dengan data yang diinginkan kepada responden yang berjumlah 64 orang dari pegawai dan 64 orang dari masyarakat.

Angket ini digunakan untuk memperoleh data dari responden mengenai kualitas pelayanan terhadap kepuasan masyarakat dan dapat mengevaluasi pelayanan yang diberikan agar dapat memberikan kepuasan bagi masyarakat sesuai dengan keinginan atau yang diharapkan masyarakat, sehingga responden dapat memberikan jawaban atas pertanyaan secara tertulis.

\section{Metode Analisis Data}

Dalam penelitian ini teknik analisis data yang digunakan adalah analisis kuantitatif dengan metode statistik deskriptif. Statistik deskriptif adalah statistik yang digunakan untuk menganalisis data yang telah terkumpul sebagaimana adanya tanpa bermaksud membuat kesimpulan yang berlaku umum. Sehingga untuk mengetahui sejauh mana hubungan dan pengaruh variabel Xterhadap Y.

\section{Analisis Deskriptif Ordinal.}

Metode ini digunakan untuk mengkaji variabel yang ada pada penelitian yaitu kualitas pelayanan (X) dan kepuasan masyarakat (Y) pada Dinas Kependudukan dan Pencatatan Sipil Kabupaten Labuhanbatu. Deskriptif persentase ini diolah dengan cara frekuensi dikali bobot 
nilai lalu dijumlahkan pada masing-masing item kemudian dibagi dengan total responden, selanjutnya dicocokkan dengan interval penilaian jawaban responden seperti dikemukan Sudjana (2001: 47) adalah sebagai berikut:

$$
\text { Panjang kelas interval }=\underbrace{\text { Rentang }}_{\text {Banyak Kelas Interval }}
$$

Dimana :

Rentang $=$ Nilai tertinggi - Nilai terendah

Banyak kelas interval $=5$

\section{Analisis Regresi}

Analisis regresi adalah regresi yang hanya menggunakan satu variable independen guna menduga variabel dependen. Ada 3 langkah tahap untuk proses analisis regresi dan korelasi (Noegroho, 2005), yaitu :

1. Menentukan persamaan regresi

2. Menentukan penyimpangan (standard error of estimated)

3. Menggunakan analisis korelasi untuk menentukan ketetapan persamaan garis regresinya Persamaan regresi adalah sebagai berikut :

$\mathrm{Y}=\mathrm{a}+\mathrm{b} X$ Dimana

$$
\begin{aligned}
& \mathrm{Y}=\text { nilai yang diduga (kepuasan masyarakat) a } \\
& =\text { intercept/konstanta } \\
& X=\text { nilai dari variabel independen (kualitas pelayanan ) } \\
& \mathrm{b}=\text { lereng garis yang berkaitan dengan variabel } \mathrm{X}
\end{aligned}
$$

Besarnya penyimpangan persamaan regresi dihitung menggunakan metode jumlah kuadrat terkecil dengan criteria pendugaan bidang jumlah kuadrat penyimpangan minimum, yakni penyimpangan titik-titik yang terletak dalam bidang. 2 persamaan yang digunakan untuk menghitung konstanta a dan b, adalah:

$$
\Sigma \mathrm{Y}=\mathrm{a}+\mathrm{b} \Sigma X
$$




$$
\Sigma X Y=a \Sigma X+b \Sigma X 1
$$

\section{Uji t}

Dari hipotesis tersebut dapat terlihat arti dari pengujian yang dilakukan, yaitu berdasarkan data yang tersedia, akan dilakukan pengujian terhadap b (koefisien regresi populasi), apakah variable independen secara parsial memiliki pengaruh yang signifikan atau tidak terhadap variabel dependen. Uji hipotesis ini dengan uji t dengan mencari thitung dan membandingkan dengan t tabel. Mencari t hitung dengan rumus :

$$
\begin{aligned}
& \text { thitung }=\frac{r \sqrt{n-2}}{\sqrt{1-r^{2}}} \\
& \text { Dimana : } \\
& \mathrm{r}=\text { koefisien korelasi } \mathrm{n} \\
& =\text { jumlah data }
\end{aligned}
$$

Kriteria hipotesis diterima atau ditolak Kaidah pengujian :

Ho ditolak jika t hitung $\geq$ dari t tabel, maka signifikan

Ho diterima jika $\mathrm{t}$ hitung $\leq$ dari $\mathrm{t}$ tabel, maka tidak signifikan

Nilai t hitung dapat diketahui dari hasil perhitungan analisis regresi

\section{HASIL DAN PEMBAHASAN}

Hasil uji validitas tersebut menunjukkan bahwa semua indikator memiliki nilai $\mathrm{R}$ hitung lebih besar dibanding $\mathrm{R}$ tabel $(0,349)$ dengan nlai terkecil 0,608 dengan nilai terbesar 0,929, hal ini menunjukkan bahwa kedua kelompok data tersebut baik responden kepuasan maupun kualitas data valid dan dapat digunakan untuk analisis selanjutnya.Hal ini sesuai dengan yang dikemukakan oleh Simamora $(2004 ; 177)$ bahwa nilai validitas diatas 0,349 menunjukkkan data penilitian yang valid.

Berdasarkan uji reliabilitas didapatkan nilai sebesar 0,767 untuk variable kualitas pelayanan dan 0,797 untuk kepuasan masyarakat. Berdasarkan hasil tersebut semua item dalam penelitian ini dikatakan reliable atau handal karena nilai koefisien reliablitas Croncbach's Alpha > 0,60, hal ini sesuai dengan pernyataan Simamora $(2004 ; 177)$ bahwa Reliabilitas suatu konstruk variable dikatakan baik jika memiliki nilai Cronbach's Alpha > 
0,60. Data yang reliable sangat berguna untuk meyakinkan hasil analisis data yang bias dipertanggung-jawabkan dan mendekati keadaan yang sesungguhnya.

Analisis Statistik Inferensialhasil perhitungan koefisien korelasi adalah 0,036. Hal ini menunjukkan keeratan hubungan antara variable kualitas pelayanan terhadap kepuasan masyarakat sangat rendah karena berada dibawah interval 0,800-1,000. Dengan kata lain kualitas pelayanan yang meningkat pada Dinas Kependudukan dan Pencatatan Sipil Kabupaten Labuhanbatu memiliki efek yang sangat kecil terhadap kepuasan masyarakat. Hal itu ditujukan dengan koefisien determinasi Multiple $\mathrm{R}^{2}$ pada tabel 4.11 sebesar $0,01=1 \%$, hal ini berarti variable peningkatan kualitas pelayanan hanya berpengaruh sebesar $1 \%$ terhadap peningkatan kualitas masyarakat.

Pengujian Hipotesis didapatkan persamaan :

$$
Y=22,96+0,053 X
$$

Berdasarkan persamaan tersebut menunjukkan bahwa nilai koefisien X sebesar 0,053 yang berarti apabila kualitas pelayanan (X) meningkat satu poin maka kepuasan masyarakat hanya meningkat sebesar 0,053 poin. Hal ini didukung dengan nilai Multiple $\mathrm{R}^{2}$ sebesar $1 \%$ menunjukkan 99\% perubahan variable kepuasan masyarakat (Y) tidak dapat diterangkan oleh pengaruh kualitas pelayanan (X) sehingga perlu dilakukan evaluasi pelayanan oleh pihak luar dan penelitian faktor lain yang menjadi penyebab rendahnya kepuasan masyarakat. Hal ini didukung dengan hasil uji $\mathrm{T}$ berdasarkan nilai t hitung 0,288 dengan signifikasi 0,775>0,05 hal ini menunjukkan bahwa perbaikan kualitas pelayanan tidak berpengaruh nyata terhadap kepuasan masyarakat.

\section{KESIMPULAN}

Berdasarkan hasil penelitian kualitas pelayanan di Dinas Kependudukan dan Pencatatan Sipil Kabupaten Labuhanbatu tidak berpengaruh signifikan terhadap kepuasan masyarakat yang membutuhkan pelayanan tersebut, hal ini ditunjukkan dengan rendahnya nilai $\mathrm{R}^{2}$ sebesar 0,01 dan hasil uji $\mathrm{T}$ menunjukkan tidak signifikan antara kualitas pelayanan terhadap kepuasan masyarakat. 


\section{Jurnal Ecobisma Vol 1 No. 12014}

\section{DAFTAR PUSTAKA}

Afifah, Fariz. 2013. Partisipasi Masyarakat Dalam Pengawasan Pelayanan Publik: Studi Kasus Implementasi Program Audit Sosial di LOD DIY.Yogyakarta : UNY.

Arikunto, Suharsimi. 2010. Manajemen Penelitian. Jakarta : PT Rineka Cipta.

Badan Pusat Statistik Sumatera Utara. 2013. "Labuhanbatu Dalam Angka 2012”, Labuhanbatu

Boedijoewono, Noegroho. 2007. Pengantar Statistika Ekonomi dan Bisnis.Yogyakarta : STIE YKPN.

Dinas Kependudukan dan Catatan Sipil Labuhanbatu. 2016. " Profil Perkembangan Kependudukan Kabupaten Labuhanbatu Tahun 2016. Rantauprapat.

Djati, S. Pantja. 2005. Pengaruh Kinerja Karyawan Terhadap Kepuasan, Kepercayaan, dan Kesetiaan Pelanggan. Jurnal Online, diakses 29Maret 2013.

Ghozali, Imam, 2005. Aplikasi Analisis Multivariate dengan Program SPSS, Edisi Ketiga, Badan Penerbit Universitas Diponegoro, Semarang Harahap, Yohana Andriani. 2017.

"Pengaruh Kecerdasan Emosional, Karakteristik Pegawai, Motivasi Kerja dan

Disiplin Terhadap Kinerja Pegawai Di Dinas Kependudukan dan Pencatatan Sipil Kabupaten Labuhanbatu". Tesis, Fakultas Ekonomi Universitas Islam Sumatera Utara. Medan.

Hardiyansyah. 2011. Kualitas Pelayanan Publik. Yogyakarta : Gava Media.

Heidracman dan Husnan, Suad. 2002. Manajemen Personalia. Yogyakarta : BPFE.

Ibnu. 2008. “Kepuasan Pelanggan”. http://ibnudblog.blogspot.com. diakses 29 Maret 2013.

Juwandi, Hendy Irawan. 2004. Kepuasan Pelayanan Jasa. Jakarta : Erlangga.

Kotler, Philip. 2003. Manajemen Pemasaran. Jakarta : Gramedia.

Kurniadi, Fajar. 2012. "Pengaruh Kompensasi dan Motivasi Terhadap Kinerja Karyawan di Apotek Berkah”. Skripsi Fakultas Bisnis dan Manajemen Universitas Widyatama. Bandung.

Moenir. 2006. Manajemen Pelayanan Umum Indonesia. Jakarta : Bumi Aksara. 
Muhson, Ali. 2009. Modul Aplikasi Komputer II. Program Studi Pendidikan Ekonomi UNY. Yogyakarta

Pedoman Umum Penyusunan Indeks Kepuasan Masyarakat Unit Pelayanan Instansi Pemerintah. 2004. Keputusan Menteri Pendayagunaan AparaturNegara Nomor: KEP/25/M.PAN/2/2004. Kementerian Pendayagunaan Aparatur Negara Republik Indonesia.

Prawirisentono, Suyadi. 1999. Kebijakan Kinerja Karyawan. Yogyakarta : BPFE.

Simamora, Henry, 2004. Manajemen Sumber Daya Manusia, Edisi Ketiga, Bagian Penerbit STIE YKPN, Yogyakarta.

Utami, Santi Budi. 2013.” Pengaruh Kualitas Pelayanan Dan Kinerja Karyawan Terhadap Kepuasan Nasabah Pada Pt. Taspen (Persero) Cabang Yogyakarta”. Program Studi Akuntansi Di Fakultas Ekonomi Universitas Negeri Yogyakarta.Yogyakarta 